\title{
İlkokul Öğrencilerinde Akran Zorbalığı: Ankara Pursaklar Örneği
}

\author{
DOI: 10.26466/opus.758653
}

*

\author{
Semira Hamurcu * \\ * Öğretmen, Yıldırım Beyazıt Ilkokulu, Ankara \\ E-Posta: hamurcusemira@gmail.com \\ ORCID: $\underline{0000-0003-1072-0231}$
}

\section{Öz}

Eğitim-öğretim etkinliklerini olumsuz yönde etkileyen akran zorbalı̆̆ının psikolojik ve sosyal etkileri sadece okul yıllarıyla sınırlı kalmayıp ilerleyen yillarda da etkilerini göstermektedir. Bu olumsuz etkiler sadece zorbalığa maruz kalan kurbanların değil, aynı zamanda zorbalığa tanık olan ve zorbaca davranışları gerçekleştiren öğrencilerin de hayatların etkilemektedir. Kısa dönemde okuldan uzaklaşmak, okul devamsızlı̆̆ı, akademik başarısızlı gibi toplumsal uyum sorunlarını, uzun dönemdeyse kayg, depresyon, intihar gibi psikolojik problemlerin yanı sıra fizyolojik problemlerin de kaynă̆ın oluşturabilen akran zorbalı̆̆ına zorbalık ortaya çıkmadan müdahale etmek ve bu davranışları önlemeye çalışan araştırmaların yapılması gerekmektedir. Zorbalı̆̆a yol açan problemlerin nedenlerinin analiz edilmesi, probleme uygun girişimlerin planlanı uygulanması, sonuçlarının değerlendirilmesi gerekmektedir. Bu çalışmanın amacı da, ilkokul 3. ve 4. sını öğrencilerinin maruz kaldıkları zorbalık türlerini, bunların görülme sıklğ̆ını, zorbalığın kim tarafından yapıldığıı tespit etmek, zorbalığın görülme türünü sınıf düzeyi ve cinsiyete bağh olarak incelemek ve mevcut durumu ortaya koymaktır. Araştırma kapsamında veri toplamak amacıyla, öğrencilerin maruz kaldıkları zorbalık türlerinin neler olduğunu, ne sıklıkla gerçekleştiğini ve bu eylemlerin kim tarafindan yapıldığını belirlemek amacıyla araştırmacı tarafından oluşturulan anket formu uygulanmıştır. Araştırmaya $140 \mathrm{klz}, 160$ erkek olmak üzere toplam 300 ö̆̆renci katılmıştır. Uygulama sonunda anket formunda yer alan sorular yüzde ve frekansları hesaplanarak tablolar halinde özetlenmiştir. Araştırma deseni nicel yöntem üzerine kuruludur. Sahadan elde edilen veriler sonucunda görülmüştür ki, erkek öğrenciler fiziksel zorbalık davranışlarına sınıf fark etmeksizin kız öğrencilere göre daha fazla maruz kalmaktadırlar. İlkokul öğrencilerinin okullardaki akran zorbalığı davranışına maruz kalmak veya tanık olmalarını kendi algılarına dayalı olarak değerlendirmeleri nedeniyle elde edilecek bulgular sinırlılı gösterebilir.

Anahtar Kelimeler: İlkokullarda akran zorbalı̆̆ı, zorbalık, okul zorbalı̆̆ı. 


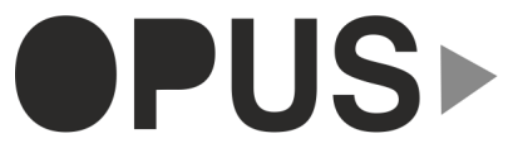

Uluslararası Toplum Araştırmaları Dergisi International Journal of Society Researches
E-ISSN : 2528-9535

YIl Year: 10

Cilt Volume: 16

Sayı Issue :Eğitim ve Toplum Özel Sayısı

Aralık December 2020

Makalenin Geliş Tarihi Received Date: 26/06/2020

Makalenin Kabul Tarihi Accepted Date: 29/12/2020

\title{
Peer Bullying In Primary School Students: The Case of Ankara Pursaklar
}

\begin{abstract}
Psychological and Social impacts of Peer Bullying affecting education and training activities adversely is not only limited with school years but may (also) persist through upcoming years. These negative impacts affect not only the life of victims but the outsiders as well as the bullies executing the hostile act. Sourcing to the problems such as alienation from school, absenteeism and academic failure in terms of social compliance in the short term and problems such as anxiety, depression and suicidality in terms of psychological problems in the long term as well as those leading to psysiological ones, Peer Bullying is requisite to be prevented before it occurs and necessary research ought to be done. It's crucial to aralayze the causes of the problems and find the accurate solutions and do the summative assessment for the problems leading to bullying. The aim of this study is to determine the types of bullying, the prevalence of it and who the doers are among the third and fourth grade students depending on class level and gender in order to reveal the current situation. Within the research a questionnarie form held by the researcher is used to collect data searching for the types of bullying, the frequency of it and who the doers are. The participants are 140 girls and 160 boys, 300 students in total. The results in the questionnarie are summed up in charts in percentage and frequency calculations. The research design is based on quantitative method. As a result of the data obtained from the field, it was seen that male students are more exposed to physical bullying behaviors than female students regardless of their class. Findings to be reached may indicate limitedness as they evaluate the situation according to their perception for the Primary School Students exposed to Peer Bullying as a victim or an outsider.
\end{abstract}

Keywords: Peer bullying, bullying, school bullying in primary schools. 


\section{Giriş}

Sanayi toplumundan bilgi toplumuna gelinen yirmibirinci yüzyılda her alanda olduğu gibi eğitim kurumunda da eski ilkelerin değiştiği, yeni bir paradigmanın oluşmaya başladığı görülmektedir. Bilgiye dayalı yeni toplum düzeni oluşturulurken, değişen öğrenme ve öğretme biçimlerimizle birlikte eğitim kurumlarından beklentilerimiz de farklılaşmaktadır. Karar alma sürecine velileri ve öğrencileri dahil etmek, etkili teknoloji kullanımı, merkezine öğretmenin değil öğrencinin ilgi ve yeteneklerinin konacağı bir örgütlenme, ders programları ve saatlerinin öğrencilere göre düzenlenmesi, etkinliklerin farklı zeka türlerini ortaya çıkaracak şekilde programlanması gibi hedefler beklentilerin sadece bir kısmını oluşturmaktadır. Tüm bu beklentilerin yanı sıra ilk hedef hiçbir zaman değişmemektedir: Çocuklarımızın okul ikliminde her türlü risk ve tehlikeden uzak tutulması ve korunması.

Okul iklimini olumsuz etkileyen etmenlerin başında vandalizm, şiddet, teknoloji ve internet bağımlılı̆̆ı, zorbalık, akran zorbalığı, siber akran zorbalığı gibi olaylar gelmektedir. Okul ortamını olumsuz etkileyerek öğrencilerde korku ve kaygı hissi yaratan bu olaylar devamsızlık ve okula yabancılaşma hatta ileri yıllarda okulu terk etme gibi davranışlara neden olabilmektedir.

Çocukların hızlı bir fiziksel ve psikolojik gelişme süreci içinde olmaları onların davranışlarına da yansımaktadır. Çocuklar hem şiddetin uygulayıcısı hem de mağduru olabilmektedir. Öğrenciler arası şiddet olaylarının medyada sıklıkla yer alması, okulda şiddet olaylarının kaygı verecek düzeyde olduğu tartışmalarını da beraberinde getirmektedir. En sade biçimiyle şiddet; insanlara fiziksel ve ruhsal olarak zarar veren her türlü davranış olarak değerlendirebilir. "Yaşça daha büyük ya da fiziksel olarak daha güçlü olan öğrencilerin kendilerinden daha güçsüz olan çocukları hırpalaması, eziyet etmesi ve rahatsız etmesi" olarak tanımlanan "okul zorbalığı" (school bullying) kavramı (Pişkin, 2002) ise öğrencilerin birbirlerine yönelik şiddetini ele almaktadır. Akran zorbalığı olarak da isimlendirilebilen bu kavram, dövme, tokat atma, itme, çekme, dürtme, korkutma, alay etme, kızdırma, kötü isim takma, hakaret etme ve küçük düşürme gibi fiilleri içermektedir. Olweus'e (1994) göre akran zorbalığı; eşit güce sahip olmayan akranlar arasında daha güçsüz olanın daha güçlü olan bir kişi veya daha fazla kişinin olumsuz eylemlerine sürekli olarak maruz bırakılmasıdır. Kartal (2009) ise akran zorbalığını, zorba ve kurbanlar arasında öğretmen ve öğrencilerin de bulunduğu 
sosyal bağlamda gerçekleşen olumsuz bir etkileşim olarak tanımlamaktadır. Bu etkileşim, kurbanın yalnızca okul hayatında değil, yetişkinlik hayatında da etkili olabilecek uzun süreli bir olgu olarak görülmektedir.

Okullarda her geçen gün daha fazla akran zorbalığı davranışlarının görülmesiyle birlikte bu konuda daha çok araştırma yapılmaya başlanmıştır. Alan yazında akran zorbalığı ile ilgili pek çok çalışma bulunmaktadır. Zorbalık ile ilgili çalışmaların ilk olarak İskandinav ülkelerinde ele alındığı görülmektedir (Gökler, 2007). Alsaker (1993), çalışmasında 5-7 yaşları arasındaki Norveçli 120 çocuğun $\% 12,5^{\prime}$ inin potansiyel kurban olabileceğini ifade etmektedir. Perren ve Alsaker (2006), çalışmalarında kurban, zorba, hem kurban hem zorba rolündeki çocukların davranışlarını incelemişlerdir. Çalışma sonucunda kurbanların daha itaatkar, çekingen daha az işbirlikçi oldukları ortaya koyulurken, zorba ve hem kurban hem zorba çocukların daha fazla saldırgan oldukları ifade edilmiştir. Yine bu çalışmada tıpkı kurban rolündeki çocuklar gibi hem kurban hem zorba çocukların da daha az işbirlikçi oldukları belirlenmiştir. Ayrıca zorba rolündeki çocukların liderlik özelliklerinin üst düzeyde olduğu da saptanmıştır. Kartal (2009), öğretmen adaylarının uygulama okullarındaki zorbalıklarla ilgili değerlendirmelerini incelediği araştırmasında, en çok sözel zorbalığın gerçekleştiği, zorbalığı en çok uygulayanların erkek öğrenciler olduğu ve zorbalığın en ağır basan nedenlerinden birinin kurbanlardaki konuşma güçlüğü olduğu ifade edilmiştir. Burnukara ve Uçanok (2012), tarafından yapılan araştırmada 868 ortaokul ve lise öğrencisiyle çalışılmış ve bu öğrencilerin \%31,9'unun akran zorbalığ1 davranışına maruz kaldığı belirtilmiştir. Çelik, Çelen, ve Seferoğlu'nun (2015) ortaokullardaki siber zorbalığı inceledikleri araştırmalarında öğrencilerin \%47,1'inin başkalarının uğradığı siber zorbalığa tanık olduğu, \%48'inin ise siber zorbalığa maruz kaldığı ifade edilmiştir. Salı'nın (2014) araştırmasında erkek çocuklarının kız çocuklarına oranla daha fazla akran zorbalığı davranışında bulunduğu belirtilmiştir. Metin- Aslan ve Tuğrul'un (2013) çalışmasında okul öncesi zorbalığa uğrayan çocukların bu tarz davranışlara okul bahçesi gibi büyük çocuklarla bir araya geldikleri ortamlarda maruz kaldıkları ifade edilmiştir. Güven' in (2015), 200 ortaokul öğrencisi ile yaptığı çalışmasında düşük sosyoekonomik düzeyden gelen öğrencilerin daha fazla kurban rolünde olduğu ve erkek öğrencilerin kız öğrencilere göre daha fazla zorba oldukları tespit edilmiştir. Akyol, Yıldız ve Akman'ın (2018) öğretmenlerin akran zor- 
balığına ait görüşlerini aldıkları çalışmalarındaki araştırma bulgularına bakıldığında, küçük yaş grupları ile çalışan öğretmenlerin fiziksel zorbalıkla, daha büyük yaş grupları ile çalışan öğretmenlerin ise psikolojik/duygusal ve sözel zorbalıkla karşılaştıkları sonucuna ulaşılmaktadır. Gültekin Akduman'ın (2010), 7-14 yaş çocuk gruplarıyla yaptığı çalışmada, 7-8 yaş çocuklarında açık saldırı yani fiziksel şiddete daha fazla rastlandığı görülmektedir. Yaşla beraber fiziksel saldırganlığın azaldığı ve konuşma becerilerinin gelişmesi ile sözel saldırıların arttığı da tespit edilmektedir.

Bu bilgiler ışığında, ilkokul kademesinde eğitim gören öğrencilerin akran zorbalığının türlerine, sıklığına ve zorbaca davranışların kim tarafından yapıldığına dair görüşlerinin araştırılması akran zorbalığını önlemeye yönelik çalışmalara katkı sağlayacaktır.

$\mathrm{Bu}$ çalışmanın konusu, ilkokul öğrencilerinde görülen akran zorbalığı davranışlarının meydana gelme nedenleri ve bu davranışların yoğunluğunun cinsiyet, etnik köken, okuldaki sınıf düzeyi gibi demografik değişkenlere göre nasıl farklılaştığı, zorbalığa maruz kalmada bu değişkenlerin risk faktörü olup olmadığını ortaya çıkarmaktır. Bu araştırmanın amacı ise, ilkokul öğrencilerinin karşılaştıkları akran zorbalığı davranış tiplerini, bu davranışların gerçekleşme sıklığını ve bu davranışların kim tarafından yapıldığını tespit etmektir. Araştırmanın alt amacı ise karşılaşılan akran zorbalığı davranışlarının cinsiyet ve yaş açısından farklılık gösterip göstermediğini saptamaktır. Türkiye'de ilkokullarda akran zorbalığı ile ilgili yapılan araştırmalar oldukça sınırlıdır. Akran zorbalığının ilkokullardaki genel görünümü hakkında bilgi edinmek öğrencilerin ileri yaşlarda karşılaşabilecekleri zorbalık davranışlarının önüne geçebilmek açısından oldukça önemlidir. Akran zorbalığı, kısa dönemde okuldan uzaklaşmak, okul devamsızlığı, akademik başarısızlık gibi toplumsal uyum sorunlarını, uzun dönemdeyse kaygı, depresyon, intihar gibi psikolojik problemlerin yanı sıra fizyolojik problemlerin de kaynağını oluşturmaktadır. Bu tür sorunlarla karılaşmamak için zorbalık ortaya çıkmadan önce duruma müdahale edip, bu davranışları önlemeye çalışmak ve esas olarak da bu tür davranışları önlemeye yönelik araştırmaların yapılması gerekmektedir.

Zorbalığa yol açan nedenlerin analiz edilmesi, probleme uygun girişimlerin planlanıp uygulanması, sonuçlarının değerlendirilmesi gerekmektedir. $\mathrm{Bu}$ araştırma bağlamında zorbalık olaylarına müdahale edilmesi için ilişkili 
olduğu düşünülen cinsiyet ve okuldaki sınıf düzeyi faktörlerinin incelenmesi, okullardaki akran zorbalığı davranışları hakkında öğrenci görüşlerinin belirlenmesi oldukça önemlidir. Bu araştırmanın verileri ile mevcut yazındaki ilkokullarda akran zorbalığ tartışmalarına ilave olarak akran zorbalığ davranışına, cinsiyet ve sınıf düzeyi açısından yeni bir katkı sağlayabilmek amaçlanmaktadır. Çalışma ile elde edilen nicel veriler, sosyal bilimler alanında önemli bir yere sahip zorbalık, akran zorbalı̆̆ı, şiddet, okul kültürü, cinsiyet ve sınıf düzeyi değişkenlerinin birbirleriyle ilişkilerinin açıklanması ve bu alanda araştırma yapacaklara katkı sunması açısından önem arz etmektedir.

\section{Problem Durumu}

İlkokul öğrencilerinin akran zorbalığına ilişkin görüşleri nelerdir?

\section{Araştırmanın Alt Problemleri:}

- İlkokul üçüncü ve dördüncü sınıf öğrencilerinin maruz kaldıkları akran zorbalığı türleri nelerdir?

- İlkokul üçüncü ve dördüncü sınıf öğrencilerinin maruz kaldıkları akran zorbalığı davranışlarının görülme sıklığı nedir?

- Akran zorbalığı davranışının nedenleri ve görülme sıklı̆̆ı sınıf düzeyi ve cinsiyete göre farklılaşmakta mıdır?

- Hangi zorba davranışlar cinsiyet açısından anlamlı bir farklılık göstermektedir?

- Akran zorbalığı görülme sıklığında, üçüncü ve dördüncü sınıf düzeyleri arasında anlamlı bir fark var mıdır?

\section{Yöntem}

Bu araştırmanın evreni Ankara' daki ilkokullardır. Araştırma, Ankara ili Pursaklar ilçesindeki 2000 mevcutlu Saray İlkokulu'ndaki 3. ve 4. Sınıf öğrencilerini oluşturan 907 kişilik bir öğrenci grubundan sınırlı bir zaman dilimi içerisinde akran zorbalığı davranışı hakkında bilgi toplamayı hedeflemiştir. Milli Eğitim Bakanlığı'ndan ve Hacı Bayram Veli Üniversitesi'nden gerekli etik izin alındıktan sonra hazırlanan anketler, toplamda 300 öğrenciye, 22-26 Nisan 2019 tarihinde uygulanmıştır. Bu çerçevede araştırma bir tarama araştır- 
ması (survey) olma özelliğine sahiptir. Yani araştırmacı bir yandan anket yaparken diğer yandan anketten elde edilen verilerin eksik kalması durumunda eksiklikleri mülakatlar yaparak tamamlamaya çalışmıştır. Ayrıca araştırmacının öğretmen olması, öğrenci davranışlarının doğrudan gözlem yoluyla incelenmesini mümkün kılmaktadır.

Anket yoluyla elde edilen verinin analizi sonucunda, araştırmaya katılan bireylerin düşünce, tutum ve görüşlerini belirlemek, çeşitli çıkarımlarda bulunmak ve karşılaştırmalar yapmak mümkün olabilmektedir (Gürbüz ve Şahin, 2017, s.175), bu eksende anket araştırma için uygun bir veri toplama tekniği olarak görülmüştür. Bu teknik aracılığıyla, araştırma yapılan alanla ilgili ulaşılan veriler daha önce yapılan araştırma sonuçlarıyla mukayese edilebilecektir. Böylece araştırma hem literatür üzerinden bir sağlama yapmayı hem de daha önce yapılan benzeri araştırma sonuçlarını test etmeyi hedeflemiştir.

Veri toplama sürecine geçilmeden önce Ankara Valiliği Milli Eğitim Müdürlüğünden çalışma kapsamında araştırma izni alınmıştır. Ankara Hacı Bayram Veli Üniversitesi Etik Komisyonundan alınan etik onay ile araştırma süreci başlamıştır. Etik onay ve uygulama izni evrakları ekte sunulmuştur. Öğrenciler sınıflarında, öğretmenlerinin de eşliğinde kendi bildirimlerine dayanan ve etik ilkelere ilgili mevzuatı takip ederek bağlı kalınan anketi doldurmuşlardır. Anket uygulanmadan önce her sınffta öğrencilere anket hakkında bilgi veren konuşma yapılmıştır. Her sınıfta kısa bir sohbetten sonra, kendileri ve okulda yaşadıkları kimi güçlükler hakkında sorular sorulmuş, bunun bir test ya da sınav olmadığı, soruların doğru ya da yanlış cevaplarının bulunmadığı özellikle ifade edilmiştir. Verdikleri yanıtların gizliliği konusunda güvence verilip, işbirliklerinden dolayı teşekkür edilmiştir.

$\mathrm{Bu}$ araştırmanın temel varsayımı, öğrencilerdeki zorbalık davranışını ölçmek için geliştirilen anketin güvenilir ve geçerli bir ölçüm aracı olmasıdır. Araştırmanın diğer bir varsayımı, akran zorbalığı davranışının zorbalığa maruz kalan öğrencinin eğitim sürecini olumsuz etkileyeceğidir.

Araştırma 2018-2019 eğitim öğretim yılında Ankara ili, Pursaklar ilçesi ilkokullarında öğrenim gören üçüncü ve dördüncü sınıf öğrencileri ile sınırl-dır. İlkokul öğrencilerinin okullardaki akran zorbalığı davranışına maruz kalmaları veya tanık olmalarının kendi algılarına dayalı olarak değerlendirilmesiyle sınırlıdır. İlkokul üçüncü ve dördüncü sınıf öğrencilerine uygulanan anket formunun ölçtüğü niteliklerle sınırlıdır. 


\section{Bulgular}

Bu bölümde sahada uygulanan anket sorularından hareketle elde edilen verilerin betimsel analizi sunulacaktır. Anketler ilköğretim 3. ve 4. Sınıf öğrencilerine uygulanmış olup aşağıdaki veriler onların anket sorularına verdikleri cevapların analizidir.

\section{Demografik Bulgular}

Tablo 1. Cinsiyet

\begin{tabular}{llll}
\hline & Frekans & Yüzde & Geçerli Yüzde \\
\hline Kız & 140 & 46,7 & 46,7 \\
\hline Erkek & 160 & 53,3 & 53,3 \\
\hline Toplam & 300 & 100,0 & 100,0 \\
\hline
\end{tabular}

Araştırmaya katılan öğrencilerin \%46.7'si kız ve \%53.3'ü erkek öğrencilerden oluşmaktadır. Bilinçli bir tercih olmamakla birlikte öğrencilerin eşit dağılıma sahip olduğu görülmektedir.

Tablo 2. SinıfDüzeyi

\begin{tabular}{clll}
\hline Sinıf & Frekans & Yüzde & Geçerli Yüzde \\
\hline 3. Sinıf & 147 & 49,0 & 49,0 \\
\hline 4. Sinıf & 153 & 51,0 & 51,0 \\
\hline Toplam & 300 & 100,0 & 100,0 \\
\hline
\end{tabular}

Öğrencilerin \%49'u üçüncü sınıf, \%51'i dördüncü sınıf öğrencilerinden oluşmaktadır. Araştırmaya katılacak öğrencilerin seçiminde bu yüzdelerin birbirine yakın olması bilinçli bir tercih olmuştur.

Tablo 3. Anne Eğitim Düzeyi

\begin{tabular}{llll}
\hline & Frekans & Yüzde & Geçerli Yüzde \\
\hline Okuryazar & 51 & 17,0 & 17,0 \\
\hline İlkokul ve Ortaokul mezunu & 152 & 50,7 & 50,7 \\
\hline Lise mezunu & 71 & 23,7 & 23,7 \\
\hline Yüksekokul ve üniversite mezunu & 26 & 8,7 & 8,7 \\
\hline Toplam & 300 & 100,0 & 100,0 \\
\hline
\end{tabular}

Öğrencilerin annelerinin \%17'si okur-yazar ya da değil, \%50'si ilkokul ve ortaokul mezunu, \%23'ü lise mezunu, \%8'i yüksekokul ve üniversite mezunudur. Anne eğitim düzeyi daha çok ilk-orta ve lise eğitim düzeyinde yoğunlaşmaktadır, toplamda \%74.4. Bunun anlamı anket uygulanan her dört 
öğreniciden üçünü bu grup oluşturmaktadır. Her on öğrenciden ancak yaklaşık birinin annesi yüksekokul ya da üniversite mezunu durumundadır.

Tablo 3. Baba Eğitim Düzeyi

\begin{tabular}{llll}
\hline & Frekans & Yüzde & Geçerli Yüzde \\
\hline Okuryazar & 39 & 13,0 & 13,0 \\
\hline İlkokul ve Ortaokul mezunu & 119 & 39,7 & 39,7 \\
\hline Lise mezunu & 95 & 31,7 & 31,7 \\
\hline Yüksekokul ve üniversite mezunu & 47 & 15,7 & 15,7 \\
\hline Toplam & 300 & 100,0 & 100,0 \\
\hline
\end{tabular}

Öğrencilerin babalarının \%13'ü okur-yazar ya da değil, \%39'u ilkokul veya ortaokul mezunu, \%31'i lise mezunu, \%15'i yüksekokul veya üniversite mezunudur. Bu yüzdeler anne eğitim düzeyi tablosundaki yüzdelere oldukça yakındır. Tıpkı anne eğitim düzeyi yüzdelerinde olduğu gibi baba eğitim düzeyi yüzdelerinde de en yüksek oran ilkokul veya ortaokul mezunu oranıdır. Eğitim düzeyinin düşüklüğü kaynaklı sosyal bakımdan zayıf ailelerden gelen öğrencilerin zorbalık davranışlarını gerçekleştirme nedenleri bu öğrencilerin etraflarına duydukları kıskançlık olabilir. Nitekim Gökler(2009)'e göre de zorbalığın nedenleri, zorbaların sosyal bakımdan zayıf ailelerden gelmeleri sebebiyle etraflarına kıskançlık ve nefret duyguları beslemeleri olabilir.

\section{Fiziksel Zorbalık Bulgularn}

Tablo 5 Okulundaki öğrenciler seni itti mi?

\begin{tabular}{llll}
\hline & Frekans & Yüzde & Geçerli Yüzde \\
\hline Asla & 100 & 33,3 & 33,3 \\
\hline Haftada 1-2 gün & 171 & 57,0 & 57,0 \\
\hline Haftada 3 ve daha fazla gün & 29 & 9,7 & 9,7 \\
\hline Toplam & 300 & 100,0 & 100,0 \\
\hline
\end{tabular}

İtme davranışından birine yumruk vurarak şiddet uygulamaya kadar farklı türleri olan okuldaki şiddet, zorbalık davranışının araştırma grubu içindeki örneği Tablo 5'de itme davranışı örneği ile ele alınmıştır. Okuldaki öğrenciler tarafından asla itilmediğini belirten öğrencilerin oranı \%33'tür. $\mathrm{Bu}$ durumda her üç öğrenciden birinin itme davranışına maruz kalmadığı görülmektedir. Haftada 3 ve daha fazla gün itme davranışına maruz kalanların oranı ise $\% 9^{\prime}$ da kalmaktadır. Yani her on öğrenciden birisi haftada üç ya da daha fazla kez bu davranışa maruz kaldığını belirtmektedir. Öğrencilerin yarısından fazlasının itme davranışına haftada bir ya da iki kez maruz kaldığı 
görülmektedir. Araştırmacının öğrenciler üzerindeki gözlemleri de bu bilgileri doğrulamaktadır. Araştırmacı öğrencilerin okula giriş ve çıkışlarında, bayrak töreni için okul bahçesinde sıra olurken, kantinde alış veriş yaparken hatta defterini göstermek için öğretmeninin yanına gelirken dahi birbirlerini itme davranışını gösterdiklerini gözlemlemektedir. İtme davranışı itme eyleminin şiddetine, karşısındakine verdiği zarara ve karşıdakinin o davranışı algilama biçimine göre normal ve patolojik arasında salınım gösterebilmektedir. Örneğin öğretmenine göstermek üzere defterini öğretmenine götüren öğrencilerin şaka yollu birbirlerini itmeleri bir zorbalık olarak değerlendirilemezken kantinde birinin önüne geçme ya da sınıfın dışına çıkarken önündekini rahatsız edici biçimde itme zorbalık davranışı kapsamına girebilmektedir.

Tablo 6. Okulundaki öğrenciler seni itti ise bu kim tarafından yapıldı?

\begin{tabular}{llll}
\hline & Frekans & Yüzde & Geçerli Yüzde \\
\hline Kız & 16 & 5,3 & 8,0 \\
\hline Erkek & 117 & 39,0 & 58,5 \\
\hline Bir grup & 67 & 22,3 & 33,5 \\
\hline Toplam & 200 & 66,7 & 100,0 \\
\hline Cevapsiz & 100 & 33,3 & \\
\hline Toplam & 300 & 100,0 & \\
\hline
\end{tabular}

İtme davranışına maruz kalan öğrenciye bu davranışı kimin yaptığına bakıldığında itme davranışının en az kız öğrenciler tarafından yapıldığı görülmektedir. Bunu \%33,5 ile bir grup ve \%58,5 ile erkek öğrenci seçeneği takip etmektedir. Uçanok ve Uludağlı da (2005) erkeklerin, kızlara oranla akran zorbalığı davranışlarını daha fazla gösterdiklerini belirlemiştir.

Tablo 7. Okulundaki öğrenciler seni tekmeledi mi?

\begin{tabular}{llll}
\hline & Frekans & Yüzde & Geçerli Yüzde \\
\hline Asla & 194 & 64,7 & 64,7 \\
\hline Haftada 1-2 gün & 83 & 27,7 & 27,7 \\
\hline Haftada 3 ve daha fazla gün & 23 & 7,7 & 7,7 \\
\hline Toplam & 300 & 100,0 & 100,0 \\
\hline
\end{tabular}

Tekmeleme davranışı itme gibi şiddet dozu belirsiz bir eylemden daha farklıdır çünkü tekme atmak doğrudan şiddet göstergesi, zorbalığın bir işareti olarak görülebilir. Okuldaki öğrenciler tarafından asla tekmelenmediğini belirten öğrencilerin oranı \%64'tür. Haftada 1-2 gün tekmeleme davranışına 
maruz kalanların oran $1 \% 27$ iken haftada 3 ve daha fazla gün tekmeleme davranışına maruz kalanların oranı \%7' de kalmaktadır. Kızmaz'a (2006) göre çocuğun gen özellikleri, karakteri ve ihtiyaçları gibi faktörler onun zorbaca eylemlere eğilimli olmasında rol oynamaktadır. Araştırmacı eğitim verdiği öğrencilerin ailelerini tanımakta ve sert mizaçlı ailelerin çocuklarının da sert mizaçlı olup fiziksel zorbalık olarak nitelendirebileceğimiz davranışlar sergilediklerine tanık olmaktadır. Bu nedenle okullarda öğrenci zorbalığını önlemenin bir yolu çocuklara yönelik rehabilitasyon programları ise diğer yönü de çocukların yetiştikleri ortam yani öncelikle aile çevresine yönelik bir iyileştirme programının hayata geçirilmesi, zorbalık davranışı sergileyen öğrencilerin ve velilerinin onları deşifre etmeyecek, rahatsız etmeyecek bir rehabilitasyon programına dahil ederek, onları izlemeye almak ve bu çerçevede dolaylı olarak okullarda meydana gelecek, gelebilme ihtimali yüksek zorbalıkların önüne geçmeye çalışmaktır.

Tablo 8. Okulundaki öğrenciler seni tekmeledi ise bu kim tarafindan yapıldı?

\begin{tabular}{llll}
\hline & Frekans & Yüzde & Geçerli Yüzde \\
\hline Kiz & 9 & 3,0 & 8,5 \\
\hline Erkek & 79 & 26,3 & 74,5 \\
\hline Bir grup & 18 & 6,0 & 17,0 \\
\hline Toplam & 106 & 35,3 & 100,0 \\
\hline Cevapsiz & 194 & 64,7 & \\
\hline Toplam & 300 & 100,0 & \\
\hline
\end{tabular}

Tekmeleme davranışına maruz kalan öğrenciye bunun kim tarafından yapıldığına bakıldığında tekmeleme davranışında en çok \%74,5'lik bir oranla erkek öğrencilerin bulunduğu görülmektedir. Bunu \%17 ile bir grup ve \%8,5'lik oranla kız öğrenciler takip etmektedir. Pişkin (2002) de öğrencilerden erkek olanların fiziksel zorbalığa daha fazla maruz kalıp, daha fazla fiziksel zorbalık davranışlarında bulunduklarını ifade etmektedir. Tekmeleme şiddet düzeyi yüksek bir zorbalık eylemi olarak görülmelidir. Davranışın şiddet düzeyi yükseldikçe daha çok erkekler tarafından şiddetin yine erkeklere yöneldiği görülmektedir. Yüksek dozlu şiddet eylemleri kız öğrencilerin maruz kaldıkları bir durum olarak görülmemektedir.

Tablo 9. Okulundaki öğrenciler sana vurdu mu?

\begin{tabular}{llll}
\hline & Frekans & Yüzde & Geçerli Yüzde \\
\hline Asla & 126 & 42,0 & 42,0 \\
\hline Haftada 1-2 gün & 127 & 42,3 & 42,3 \\
\hline Haftada 3 ve daha fazla gün & 47 & 15,7 & 15,7 \\
\hline Toplam & 300 & 100,0 & 100,0 \\
\hline
\end{tabular}


Öğrencilerin \%42'si kendilerine asla bir başka öğrencinin vurmadığını belirtmiştir. \%42'lik oranla bazı öğrenciler kendilerine diğer öğrencilerin haftada 1-2 gün sıklıkla vurduğunu, \%15'lik oranla da kendilerine haftada 3 ve daha fazla sıklıkla diğer öğrencilerin vurduğunu belirtmiştir.

Eslea ve Rees(2001), araştırmalarında zorbalığın ileri yaşlarda bile unutulmadığını belirtmektedirler. Araştırma bulgularında, zorbalık olaylarının sıklığının yaşla birlikte azaldığı da tespit edilmiştir. Totan (2008), çalışmasında, zorbalık davranışlarının üst sınıflara doğru arttığını, mağdur oranının ise üst sınıflara doğru azaldığını saptamıştır. Araştırmacının gözlemleri de bu bilgileri doğrulamaktadır. Nitekim araştırmacının öğretmeni olduğu 8 yaş grubu çocukların zorbalığa maruz kalma şikayetleri 9, 10 ve 11 yaş grubu çocuklarına yönelik olmaktadır. 8 yaş grubu çocukları üst sınıflardaki öğrenciler tarafından sıklıkla fiziksel zorbalığa maruz kalmaktadır.8 yaş grubu öğrencisi fiziksel olarak daha savunmasız ve güçsüz olduğu için üst sınıfların şiddetine, zorbalığına daha fazla maruz kalma potansiyeline sahiptir.

Tablo 10. Okulundaki öğrenciler sana vurdu ise bu kim tarafından yapıldı?

\begin{tabular}{llll}
\hline & Frekans & Yüzde & Geçerli Yüzde \\
\hline Kız & 22 & 7,3 & 12,6 \\
\hline Erkek & 114 & 38,0 & 65,5 \\
\hline Bir grup & 38 & 12,7 & 21,8 \\
\hline Toplam & 174 & 58,0 & 100,0 \\
\hline Cevapsiz & 126 & 42,0 & \\
\hline Toplam & 300 & 100,0 & \\
\hline
\end{tabular}

Öğrencilerin \%12'si kendisine vuran öğrencinin kız olduğunu, \%65'i erkek olduğunu, \%21'i ise bir grup tarafindan kendisine vurulduğunu belirtmiş̧ir. Araştırmacı teneffüs saatlerinde tuttuğu nöbetleri esnasında da gözlemler yapmakta ve başka bir öğrenciye vurarak fiziksel şiddet içeren davranışlar sergileyen öğrencilerin çoğunlukla erkek öğrenciler olduğunu gözlemlemektedir.

Tablo 11. Okulundaki öğrenciler el kol şakası yaparak seni rahatsız etti mi?

\begin{tabular}{llll}
\hline & Frekans & Yüzde & Geçerli Yüzde \\
\hline Asla & 147 & 49,0 & 49,0 \\
\hline Haftada 1-2 gün & 114 & 38,0 & 38,0 \\
\hline Haftada 3 ve daha fazla gün & 39 & 13,0 & 13,0 \\
\hline Toplam & 300 & 100,0 & 100,0 \\
\hline
\end{tabular}


Tablo 11'de görüldüğü üzere araştırmaya katılan öğrencilerin \%49'u kendisine bir başka öğrenci tarafından asla el kol şakası yapılmadığını belirtmiştir. Kendisine bir başka öğrenci tarafından haftada 1-2 gün sıklıkla el kol şakası yapıldığını belirten öğrenci oranı \%38 iken, haftada 3 ve daha fazla gün yapıldığını belirten öğrenci oranı \%13'tür. Zorbalığın cinsiyetle ilişkisini araştıran Dölek (2002), kızların kızlara, erkeklerin de erkeklere daha fazla zorba davranışlarda bulunduğunu ifade etmektedir. Araştırmacının öğrenciler üzerindeki okul içi gözlemleri de bu bilgileri doğrulamaktadır. Öyle ki kendisine el kol şakası yapıldığından şikayetçi olan kurban öğrenciler çoğunlukla zorbanın hem cinslerinden biri olduğunu ifade etmektedirler. Çoğunlukla kızların kızlarla, erkeklerin de erkeklerle oyun oynayıp vakit geçirdiği düşünüldügünde bu sonuca varılması da kaçınılmaz olmaktadır.

Tablo 12. Okulundaki öğrenciler el kol şakası yaparak seni rahatsız etti ise bu kim tarafindan yapild??

\begin{tabular}{llll}
\hline & Frekans & Yüzde & Geçerli Yüzde \\
\hline Kiz & 17 & 5,7 & 11,1 \\
\hline Erkek & 104 & 34,7 & 68,0 \\
\hline Bir grup & 32 & 10,7 & 20,9 \\
\hline Toplam & 153 & 51,0 & 100,0 \\
\hline Cevapsiz & 147 & 49,0 & \\
\hline Toplam & 300 & 100,0 & \\
\hline
\end{tabular}

\section{Sözel Zorbalık Bulguları}

Tablo 12. Okulundaki öğrenciler sana kötü sözler söyledi mi?

\begin{tabular}{llll}
\hline & Frekans & Yüzde & Geçerli Yüzde \\
\hline Asla & 100 & 33,3 & 33,3 \\
\hline Haftada 1-2 gün & 135 & 45,0 & 45,0 \\
\hline Haftada 3 ve daha fazla gün & 65 & 21,7 & 21,7 \\
\hline Toplam & 300 & 100,0 & 100,0 \\
\hline
\end{tabular}

Öğrencilerin \%33’ü arkadaşları olan diğer öğrencilerin kendisine asla kötü sözler söylemediğini belirtmiştir. Bu durumda her üç öğrenciden birinin kötü sözler işitme davranışına maruz kalmadığı görülmektedir. Haftada 3 ve daha fazla gün kötü sözler işitme davranışına maruz kalanların oranı ise \%21'de kalmaktadır. Öğrencilerin \%45'inin haftada 1-2 gün kötü sözler işitme davranışına maruz kaldığı görülmektedir. Satan (2006), öğrenciler arasındaki akademik rekabeti zorbalığın potansiyel bir sebebi olarak düşünmektedir. Araştırmacının gözlemleri de bu doğrultudadır. Öyle ki sınıf içerisinde akademik 
olarak daha başarılı öğrenciler teneffüslerde akademik yönden daha başarısız öğrenciler tarafından kötü sözlere maruz kalarak rahatsız edilebilmektedir.

Tablo 13. Okulundaki öğrenciler sana kötü sözler söyledi ise bu kim tarafından yapıldı?

\begin{tabular}{llll}
\hline & Frekans & Yüzde & Geçerli Yüzde \\
\hline Kız & 25 & 8,3 & 12,5 \\
\hline Erkek & 138 & 46,0 & 69,0 \\
\hline Bir grup & 37 & 12,3 & 18,5 \\
\hline Toplam & 200 & 66,7 & 100,0 \\
\hline Cevapsız & 100 & 33,3 & \\
\hline Toplam & 300 & 100,0 & \\
\hline
\end{tabular}

Kötü sözler işitme davranışına maruz kalan öğrenciye bu davranışı kimin yaptığına bakıldığında kötü sözler söyleme davranışının en az kız öğrenciler tarafından yapıldığı görülmektedir. Bunu \%18 ile bir grup ve \%69 ile erkek öğrenciler takip etmektedir.

Tablo 14. Okulundaki öğrenciler seni canını acıtmakla tehdit etti mi?

\begin{tabular}{llll}
\hline & Frekans & Yüzde & Geçerli Yüzde \\
\hline Asla & 221 & 73,7 & 73,7 \\
\hline Haftada 1-2 gün & 55 & 18,3 & 18,3 \\
\hline Haftada 3 ve daha fazla gün & 24 & 8,0 & 8,0 \\
\hline Toplam & 300 & 100,0 & 100,0 \\
\hline
\end{tabular}

Okuldaki öğrenciler tarafından asla tehdit edilmediğini belirten öğrencilerin oranı \%73'tür. Öğrencilerin büyük oranı diğer öğrenciler tarafından tehdit edilmediğini belirtmiştir. Öğrencilerin \%18'i haftada 1-2 gün diğer öğrenciler tarafından tehdit edildiğini belirtirken, \%8'i haftada 3 ve daha fazla gün tehdit edildiğini belirtmiştir. Zorbalık olayları okulda sınıf, tuvalet, koridor, lavabo, yemekhane, oyun alanları, okul bahçesi, okul yolu gibi okul içi ve dışı alanlarda gerçekleşebilmektedir (Dikbıyık ve Yılmaz, 2016). Okullarda meydana gelen zorbalık olaylarının nedenlerini iyi anlayıp gerekli önlemleri alabilmek için zorbalığın hangi alanlarda gerçekleştiğinin saptanması gerekmektedir. Araştırmacının gözlemleri tehdit edilme davranışına maruz kalınma oranının her geçen yıl arttı̆̆ yönündedir. Özellikle üst sınıf öğrencilerin alt sinıflardaki öğrencileri okul yolu, kantin ve lavabo gibi alanlarda tehdit ettiği öğretmenler arasında sıkça konuşulmaktadır. 
Tablo 15.Okulundaki öğrenciler seni canın acıtmakla tehdit etti ise bu kim tarafından yapildi?

\begin{tabular}{llll}
\hline & Frekans & Yüzde & Geçerli Yüzde \\
\hline Kız & 11 & 3,7 & 13,9 \\
\hline Erkek & 51 & 17,0 & 64,6 \\
\hline Bir grup & 17 & 5,7 & 21,5 \\
\hline Toplam & 79 & 26,3 & 100,0 \\
\hline Cevapsız & 221 & 73,7 & \\
\hline Toplam & 300 & 100,0 & \\
\hline
\end{tabular}

Tehdit edilen öğrenciye bu davranışı kimin yaptığına bakıldığında tehdit edilme davranışını \%64'lük oranla en çok erkek öğrencilerin yaptığı görülmektedir. Bunu \%21 ile bir grup, \%13 ile kız öğrenciler takip etmektedir.

Tablo 16. Okulundaki öğrenciler sana hakaret etti mi?

\begin{tabular}{llll}
\hline & Frekans & Yüzde & Geçerli Yüzde \\
\hline Asla & 190 & 63,3 & 63,3 \\
\hline Haftada 1-2 gün & 73 & 24,3 & 24,3 \\
\hline Haftada 3 ve daha fazla gün & 37 & 12,3 & 12,3 \\
\hline Toplam & 300 & 100,0 & 100,0 \\
\hline
\end{tabular}

Öğrencilerin \%63'ü diğer öğrencilerin kendilerine asla hakaret etmediğini belirtmiştir. Öğrencilerin \%24 ise haftada 1-2 gün sıklıkla hakarete uğradıklarını, \%12 ise haftada 3 ve daha fazla gün hakarete uğrama davranışına maruz kaldıklarını belirtmiştir. Türnüklü ve Şahin(2002) tarafından öğretmen görüşlerine dayalı olarak yapılan bir çalışmada okullarda en sık karşılaşılan çatışmalardan birinin öğrencilerin birbirlerine hakaret etmesi olduğu saptanmıştır. Karip (1999, s.13) ise kişiler arası yaşanan bu tarz çatışmaların nedenlerinin amaç farklılıkları, sınırlı kaynakların kullanımı ve özerklik isteği olabileceğini belirtmektedir.

Tablo 17. Okulundaki öğrenciler sana hakaret etti ise bu kim tarafından yapıldı?

\begin{tabular}{llll}
\hline & Frekans & Yüzde & Geçerli Yüzde \\
\hline Kız & 12 & 4,0 & 10,9 \\
\hline Erkek & 70 & 23,3 & 63,6 \\
\hline Bir grup & 28 & 9,3 & 25,5 \\
\hline Toplam & 110 & 36,7 & 100,0 \\
\hline Cevapsiz & 190 & 63,3 & \\
\hline Toplam & 300 & 100,0 & \\
\hline
\end{tabular}

Araştırmaya katılan öğrenciler kendilerine hakaret eden öğrencilerin \% 10 'unun kız öğrenci, \%63'ünün erkek öğrenci, \%25'inin ise bir grup olduğunu 
belirtmiştir. Başka bir öğrenciye hakaret etme davranışını kimin yaptığına bakıldığında bunun en az kız öğrenciler tarafından gerçekleştirildiği görülmektedir.

Tablo 18. Okulundaki öğrenciler sana küfür etti mi?

\begin{tabular}{llll}
\hline & Frekans & Yüzde & Geçerli Yüzde \\
\hline Asla & 143 & 47,7 & 47,7 \\
\hline Haftada 1-2 gün & 114 & 38,0 & 38,0 \\
\hline Haftada 3 ve daha fazla gün & 43 & 14,3 & 14,3 \\
\hline Toplam & 300 & 100,0 & 100,0 \\
\hline
\end{tabular}

Okuldaki öğrenciler tarafından kendilerine asla küfür edilmediğini belirten öğrencilerin oran $\% 47$ 'dir. Haftada 3 ve daha fazla gün kendilerine küfür edilme davranışına maruz kalanların oranı ise \%14'de kalmaktadır. Öğrencilerin \%38'i ise haftada 1-2 gün diğer öğrenciler tarafından kendilerine küfür edildiğini belirtmektedir. Sezer' in (2010), yapmış olduğu araştırma bulgularına göre okulda zorbalık en fazla sınıf içinde meydana gelmektedir. Öğrencilerin birbirlerine küfür etmesi davranışı da en fazla kalabalık sınıflar içinde yaşanmaktadır. Amaçlar, istekler ve eylemlerin çatışmasıyla problemler meydana gelmektedir. Okulun fazla kalabalık olması da öğretmenlerin problemli davranışlarla yeterince ilgilenememesine neden olmaktadır.

Tablo 19. Okulundaki öğrenciler sana küfür etti ise bu kim tarafından yapıldı?

\begin{tabular}{llll}
\hline & Frekans & Yüzde & Geçerli Yüzde \\
\hline Kız & 16 & 5,3 & 10,2 \\
\hline Erkek & 106 & 35,3 & 67,5 \\
\hline Bir grup & 35 & 11,7 & 22,3 \\
\hline Toplam & 157 & 52,3 & 100,0 \\
\hline Cevapsiz & 143 & 47,7 & \\
\hline Toplam & 300 & 100,0 & \\
\hline
\end{tabular}

Küfür etme davranışına maruz kalan öğrenciye bu davranışı kimin yaptığına bakıldığında en az kız öğrenciler tarafından küfür edildiği görülmektedir. Bunu \%22 ile bir grup, \%67 ile erkek öğrenciler takip etmektedir.

Tablo 20. Okulundaki öğrenciler sana hoşlanmadığın isimler taktı mı?

\begin{tabular}{llll}
\hline & Frekans & Yüzde & Geçerli Yüzde \\
\hline Asla & 144 & 48,0 & 48,0 \\
\hline Haftada 1-2 gün & 87 & 29,0 & 29,0 \\
\hline Haftada 3 ve daha fazla gün & 69 & 23,0 & 23,0 \\
\hline Toplam & 300 & 100,0 & 100,0 \\
\hline
\end{tabular}


Öğrencilerin \%48'i diğer öğrencilerin kendilerine asla hoşlanmadıkları isimler takmadıklarını belirtmiştir. Öğrencilerin \%29'u haftada 1-2 gün sıklıkla kendilerine hoşlanmadıkları isimler takıldığını belirtirken, \%23'ü bu davranışa haftada 3 ve daha fazla gün maruz kaldıklarını belirtmektedir. Sözel şiddetin kapsamında küfür, hakaret, tahrik, lakap takma, intiharla tehdit etme gibi eylemler yer almaktadır. Yapılan bazı araştırmalar okullarda en çok görülen şiddet türünün fiziksel şiddet olduğunu söylerken, kimi araştırmalar da en çok görülen şiddet türünün sözel şiddet olduğunu söylemektedir. Pişkin'de (2002), Ankara'daki ilkokul öğrencileri üzerinde yaptığı çalışmada öğrencilerin en fazla sözel şiddete maruz kaldığı sonucuna varmıştır.

Tablo 21. Okulundaki öğrenciler sana hoşlanmadiğın isimler taktı ise bu kim tarafından yapıldı?

\begin{tabular}{llll}
\hline & Frekans & Yüzde & Geçerli Yüzde \\
\hline Kız & 29 & 9,7 & 18,6 \\
\hline Erkek & 93 & 31,0 & 59,6 \\
\hline Bir grup & 34 & 11,3 & 21,8 \\
\hline Toplam & 156 & 52,0 & 100,0 \\
\hline Cevapsiz & 144 & 48,0 & \\
\hline Toplam & 300 & 100,0 & \\
\hline
\end{tabular}

Öğrencilere kendilerine hoşlanmadıkları isim takanların kim olduğu sorulduğunda bu isimleri takanların \%59'luk oranla en çok erkek öğrenciler olduğu belirtilmektedir. Bunu \%21 ile bir grup, \%18 ile kı öğrenciler takip etmektedir.

\section{Tartışma ve Sonuç}

Bu bölümde araştırmanın bulgu ve yorumlarına dayalı olarak ulaşılan sonuçlara ve bu sonuçlar doğrultusunda geliştirilen önerilere yer verilmiştir.

Bu araştırmanın temel iddiası iki değişken üzerinden yürütülmüştür: Sınıf düzeyi açısından akran zorbalığı arasında bir farkın olup olmadığı ve cinsiyet düzeyi açısından akran zorbalığı arasında bir farkın olup olmadığı şeklindedir.

Araştırma deseni nicel yöntem üzerine kuruludur. Nicel yönteme dayanan araştırmada saha verileri anket tekniği aracıllğı ile elde edilmiştir. Örneklem olarak seçilen Pursaklar Saray İlkokulu'nda 3. ve 4. sınıflarda toplam 300 öğrenciye uygulanan anket verileri SPSS paket programına girilerek frekans analizleri alınmıştır. Örneklemimizi oluşturan öğrencilerin anne baba eğitim 
durumlarına bakıldığında her iki kategori için de en yüksek oranı ilkokul ve ortaokul mezunlarının oluşturduğu görülmektedir.

Sahadan elde edilen veriler sonucunda görülmüştür ki, erkek öğrenciler fiziksel zorbalık davranışlarına sınıf fark etmeksizin kız öğrencilere göre daha fazla maruz kalmaktadırlar. Bu zorbalık davranışını gerçekleştirenler de elbette ki erkek öğrencilerdir.

İtme davranışına maruz kalan öğrenciye bu davranışı kimin yaptığına bakıldığında, itme davranışına en az \%8 ile kız öğrenciler, en çok \%58,5 ile erkek öğrencilerin maruz kaldığı görülmektedir. Daha önce bu konuda yapılan araştırmalar da ilgili tablolar analiz edilirken belirtildiği gibi bu oranları doğrulamaktadır. Buradan hareketle akran zorbalığının bir türü olan ve daha çok fiziksel güç gerektiren itme davranışını erkeklerin, kızlara oranla daha fazla gösterdikleri belirlenmiştir.

Doğrudan bir şiddet göstergesi olan tekmeleme davranışına maruz kalan öğrenciye bunun kim tarafından yapıldığına bakıldığında, tekmeleme davranışında en çok \%74,5'lik bir oranla erkek öğrencilerin bulunduğu görülmektedir. Bunu \%17 ile bir grup ve \%8, $5^{\prime}$ lik oranla kız öğrenciler takip etmektedir. Şiddet düzeyi yüksek bir zorbalık eylemi olarak görülmesi gereken tekmeleme davranışının daha çok erkekler tarafından gerçekleştirildiği ve yine erkeklere yöneldiği görülmektedir. Yüksek dozlu şiddet eylemleri kız öğrencilerin maruz kaldıkları bir durum olarak görülmemektedir.

Araştırmaya katılan öğrencilerin \%12,6'sı kendisine vuran öğrencinin kız olduğunu, \%65,5'i erkek olduğunu belirtmiştir. Bu oranlarda da görüldüğü gibi fiziksel zorbalık davranışlarından biri olan vurma davranışını yine erkek öğrenciler kız öğrencilere oranla daha fazla gerçekleştirmektedir. Vurma davranışı şiddetin en belirgin türlerinden biridir. İtme, tekmeleme gibi diğer şiddet davranışlarında olduğu gibi vurma eylemi de saldırganlığın davranışa yansımış halidir. Öğrencilerin öfkelerini arttıran birçok sebepten en çok göze çarpan engellenme duygusudur. İstediğine sahip olamayan, engellenen ve arzuladığı şeyi yapamayan çocuklar saldırganlaşmakta ve bunun bir dışa vurumu olarak arkadaşlarına vurabilmektedir.

Araştırmamızda el kol şakası yaparak kendisini rahatsız edenin bir kız öğrenci olduğunu belirten öğrenci oranı \%11, erkek öğrenci olduğunu belirten öğrenci oranı ise $\% 68^{\prime}$ dir. Araştırmacının yaptığı gözlemlerde el kol şakalarına en çok ders dışı zamanlarda, teneffüs ve öğle aralarında rastlandığı görülmüştür. Bu anlamda öğrencilere ders dışında ve sınıf ortamından farkll; 
kantin, okul bahçesi, spor salonu, tuvaletler ve koridorlar gibi alanlarda da davranış yeterliliği kazandırmaya yönelik aktarımlarda bulunmak ve öğrencilere olumlu davranış deneyimleri kazandırmak oldukça önemlidir. Öğrencilerin gelişiminin bir bütün olarak ele alınması ve sosyal- akademik gelişiminin birlikte takip edilmesi bir zorunluluktur.

Sahada elde edilen veriler tıpkı fiziksel zorbalık davranışlarında olduğu gibi sözel zorbalık davranışlarında da erkek öğrencilerin kız öğrencilere göre bu davranışları daha fazla gerçekleştirdiği görülmektedir.

Kötü sözler işitme davranışına maruz kalan öğrenciye bu davranışı kimin yaptığına bakıldığında kötü sözler söyleme davranışının en çok \%69'luk oran ile erkek öğrenciler tarafından yapıldığı görülmektedir. Öğrenciler kötü sözler söylediğinde bu davranışından vazgeçmesi için ceza ve kızma gibi yöntemler denemek yerine niçin kötü sözler söylediğini anlamak gerekmektedir. Öğrencinin neden kötü sözler kullandığı ve bu sözleri nereden öğrendiği önemli noktalardır. Bu soruların yanıtları öğrenildiğinde istenmeyen davranışı söndürmek daha kolay olacaktır.

Sözel zorbalık türlerinden biri olan tehdit etme davranışına bakıldığında bu davranışın en çok \%64'lük oranla erkek öğrenciler tarafından yapıldığ görülmektedir. Güvenli bir okul ortamının en önemli özelliklerinden biri öğrencilerin endişelerden uzak olmalarıdır. Öğrencilerin kendilerini güvende hissetmeleri eğitim etkinliklerinin sürdürülebilirliğinin ön koşuludur. Zorbalığı sadece fiziksel şiddet olarak gören bir bakış açısı sözel ve duygusal zorbalıkları da önemli bir sorun olarak karşımıza çıkarmaktadır. Öğrenciler evde ebeveynleri tarafından çeşitli nedenlerle tehdit söylemlerine maruz bırakıllyorsa okulda da kendisinden zayıf gördüğü öğrenciye karşı tehdit içeren söylemlerde bulunabilmektedir. Ailenin tehdit içeren sözlerden uzak durması da çocukları için bu noktada koruyucu olacaktır. Ailesinden tehdit içeren sözler duyması öğrencinin tehdit içeren sözler duyarak kurban olma ihtimalini, diğer öğrencileri tehdit ederek zorba olma ihtimalini de arttırmaktadır.

Araştırmaya katılan öğrenciler kendilerine hakaret eden öğrencilerin \% 10'unun kız öğrenci, \%63'ünün erkek öğrenci olduğunu söylemişlerdir. Aileleri tarafından ihmal edilen, aşırı katı ve dengesiz bir disiplin anlayışı ile yetiştirilen, daha çok fiziksel cezalara maruz bırakılan öğrenciler yaşadıkları aşağllık ve yetersizlik duygularının etkileri ile diğer öğrencilere hakaret boyutuna varan söylemlerde bulunabilmektedirler. Ebeveynler arasındaki kar- 
Ş1lıklı düşmanlık, aile içindeki sevgi ve saygı yoksunluğu, anne babanın çocuğu reddi veya ilgisizliği diğer öğrencilere hakaret eden öğrencilerin ailelerinde sık rastlanan durumlardır. Çocukluk döneminde oluşan bu tarz zorbalıklar kontrol altına alınmadığında ilerleyen yıllarda siyasi şiddet gibi çeşitli olgulara kaynaklık edebilmektedir.

Küfür etme davranışına maruz kalan öğrenciye bu davranışı kimin yaptığına bakıldığında \%67 ile en çok erkek öğrenciler tarafından küfür edildiği görülmektedir. Küfür eden öğrenciye anlamını bildiğini düşünerek kızmak, öğrenciyi cezalandırmak ya da utandırmak küfür etme davranışında kısa süreli bir sönmeye neden olacaktır ancak bu davranıştan tamamen vazgeçmesini sağlamak niçin küfür etmemesi gerektiğini anlatarak gerçekleşebilecektir. Öğrenciye öfkeli olduğu için bu sözleri kullandığı, öfkeli olduğunu başka sözlerle de ifade edebileceğini izah etmek cezalandırmaktan daha etkili bir yol olabilmektedir.

Araştırmaya katılan öğrencilere kendilerine hoşlanmadıkları isimler takanların kim olduğu sorulduğunda bu isimleri takanların \%59'unun erkek öğrenciler, \%18' inin ise kız öğrenciler olduğu belirtilmektedir. Öğrencilere takılan isimler öğrencilerin ekonomik yapısına, fiziksel özelliklerine, cinsiyetine, ten rengine, adına, soyadına ve dini inancına göre değişebilmektedir. Okulda diğer öğrenciler tarafından takılan isimler öğrenciler üzerinde ağır olumsuz etkiler yaratabilmektedir. Öğrencilerin birbirlerine istemedikleri isimler takmalarını engelleyebilecek en önemli kişi öğretmenlerdir. Öğrencilerin sosyal becerilerini geliştirecek ve öğrenciler arası olumlu diyalogları arttracak etkinlikler davranışın sönmesini sağlayacaktır.

Bu araştırma, İlkokul öğrencilerindeki akran zorbalığı davranışını analiz etmeyi amaçlamaktadır. Bu çerçevede yapılan saha araştırması ile Ankara'nın Pursaklar İlçesindeki Saray İlkokulundaki, örneklem olarak seçilen 3. ve 4. sınıflardaki öğrencilerinin akran zorbalığı sergileme davranışları ve bu davranışlara maruz kalan öğrencilerin ne tür akran zorbalıklarına maruz kaldıklarını ortaya çkarmayı hedeflemiştir. Bu tür çalışmaların daha sık yapılması akran zorbalığının türlerini ve buna yönelik çözüm önerilerinin tartışlarak geliştirilmesini daha da mümkün hale getirecektir. 


\title{
EXTENDED ABSTRACT
}

\section{Peer Bullying In Primary School Students: The Case of Ankara Pursaklar}

\author{
Semira Hamurcu \\ Yildırım Beyazıt First School
}

The aim of this study is to determine the types of bullying, the prevalence of it and who the doers are among the third and fourth grade students depending on class level and gender in order to reveal the current situation. With in the research a questionnarie form held by the researcher is used to collect data searching for the types of bullying, the frequency of it and who the doers are.

As some of the outcomes of the research listed, it is observed that bullying behaviors are performed as follows: It has been determined that actions which requires more physical strength like pushing, elbowing etc. as a type of peer bullying, are more common amongst male students than female students.

It is seen that the kicking action, which should be seen as an act of bullying with a higher level of violence, is mostly performed by male students and that type of bullying is also directed mostly towards other male students. Actions which contains high-dose physical violence are not observed as a common situation that female students are usually exposed to.

Yet another one of the physical bullying behaviors, the hitting one another action is also more commonly observed amongst male students than female students.

Hitting action is one of the most explicit type of violent act. Alike other acts of violence such as pushing and kicking, the act of hitting is a reflection of aggression on the action. The feeling of frustration stands out as the most common reason amidst all other reasons which may increase the anger of students. Children who cannot have what they want and cannot achieve what they desire, may feel frustrated and then become aggressive and as outcome of all may hit their friends as a way of self-expression. 
From the data obtained in the field, it is observed that, just like physical bullying behaviors, male students perform verbal bullying actions more than female students.

In the case study, when a student victimized by verbal bullying it is observed that perpetrator of the incident often be identified amongst the male students. In order to put students off verbal bullying, it is evaluated that; instead of applying punishment to repress unwanted actions, understanding of the reasons which caused verbal bullying is essential. Learning the reasons of why student choose to use verbal insults and from whom or where the student learned those words are the key points. Once the answers of those questions come to be known, extinguishing the unwanted behaviors would be easier.

The threatening action is one of the verbal bullying types and when it is examined it is observed that this action is mostly used by male students. One of the most distinguishing features of a safe school environment is that students are nothing to be worry about in the period which they spend in school. The prerequisite of the sustainable educational activity is that students to feel safe and secure. The perspective which identifies only physical violence as bullying, causes the emotional and verbal bullying as major problems which need to be confronted in educational activity. If students are exposed to threatening actions, statements and environment at their houses by their parents and their environs for various reasons, they may reflect similar attitudes and make discourses containing threats against the students whom they consider weaker than they are at school. The families to abstain from threatful discourses would be protective for their children in this manner. Exposing to threatful discourses from their families increase the possibility for the students to become victims of verbal bullying, as well as increasing the potential for them to become perpetrators who make threatful discourses and verbal bullying to other students.

Swearing action is mostly observed amongst male students. It is considered necessary to explain those students why they should not use those words to ensure them to give up this type of behavior completely.

When the behavior of telling incorrect things to others observed among the participant students of the research, it is seen that male students at the rate of $44 \%$ and the female students at the rate of $29 \%$ performed this behavior. It is evaluated that students were able to tell incorrect stories about others due 
to reasons such as one-upmanship, taking revenge, inferiority complex, and covering up their lack of social cohesion. One of the most important behaviors expected from students is cooperation with both teachers and schoolmates. Students who do not cooperate with others, on the contrary, who tells incorrect stories about others, might put both themselves and their schoolmates in exceedingly difficult situations. It is necessary to ensure that appropriate dialogues are established between students in order to prevent the undesired behavior from repeating and to reveal the truth. Teachers have great responsibility to reveal truth of the objectionable events and to ensure that undesired actions do not repeat by being clear in terms of emotions and thoughts. Teachers will help to determine possible solution options to control problems by allowing that each side to express their problems clearly.

As an outcome of the data which is obtained from the field, it was determined that some of the emotional bullying behaviors and actions were actualized and performed mostly by male students and some others performed by female students more often. It is assessed that conducting similar studies more frequently would enable to determine the types of peer bullying and create an environment to discuss the solution suggestions for it.

\section{Kaynakça / References}

Akman, B., Akyol, N.A., ve Yıldız, C. (2018). Öğretmenlerin akran zorbalığına ilişkin görüşleri ve zorbalıkla baş etme stratejileri. Hacettepe Üniversitesi Ĕ̆itim Fakültesi Dergisi, 33(2), 439-459.

Alsaker, F. (1993, March). Bully/victim problems in day-care centers, measurement issues and associations with children's psychosocial health. Paper presented at the biennial meeting of the Society for Research in Child Development, New Orleans, LA

Burnukara, P. ve Uçanok, Z. (2012). Okul ortamı ve sanal ortamda meydana gelen akran zorbalı̆g ne ölçüde örtüşüyor?. Türk Psikoloji Dergisi, 27(69), 81-96.

Çelik, A., Çelen, F. K. ve Seferoğlu, S. S. (2015). Ortaokul öğrencilerinin sanal zorbalık ve sanal mağduriyet durumlarının incelenmesi. Akademik Bilişim Konferansında sunulan bildiri, 4-6 Şubat 2015, Anadolu Üniversitesi, Eskişehir.

Dikbıyık, C., ve Yılmaz, E. (2016). Tekirdağ ölçeğinde akran zorbalığı araştırması vebulguların değerlendirmesi. Humanitas, 4(7), 126-139.

Dölek, N. (2002). Öğrencilerde zorbaca davranışlarn araştırlması ve önleyici bir program modeli. Yayınlanmamıs Doktora Tezi, Marmara Üniversitesi, Eğitim Bilimleri Enstitüsü, İstanbul. 
Eslea M., ve Rees J. (2001). At what age are children most likely to be bullied at school? Aggressive Behavior, 27(6), 419-429.

Gökler, R. (2007). İlköğretim öğrencilerinde akran zorbahŭgnın bazı değişkenler açısından incelenmesi. Yayınlanmamıs Doktora Tezi, Ankara Üniversitesi, Sosyal Bilimler Enstitüsü, Ankara.

Gökler, R. (2009). Okullarda akran zorbalı̆̆. Uluslararası İnsan Bilimleri Dergisi, 6(2), 511537.

Gültekin Akduman, G. (2010). 7-14 yaş grubu çocuklarda akran istismarı ve kendi çözüm önerileri. Kuramsal Eğitimbilim, 3(2), 13-26.

Gürbüz, S. ve Şahin, F. (2017). Sosyal bilimlerde araştırma yöntemleri. Ankara: Seçkin Yayınları, 175 .

Güven, F. (2015). Ortaokul 8. smenfögrencilerinin zorbalı yapmalar ile zorbalı̆̆a maruz kalmalarmm, cinsiyet, anne - baba eğitimi, sosyoekonomik düzey ve empati eğilimi açısından incelenmesi. Yayımlanmamış yüksek lisans tezi, Toros Üniversitesi, Mersin.

Karip, E. (1999). Çatı̧ma yönetimi. Ankara: Pegem Yayıncllık,13.

Kartal, H. (2009). Öğretmen adaylarının uygulama okullarındaki zorbalıkla ilgili değerlendirmeleri. Gazi Eğitim Fakültesi Dergisi, 29(1), 141-172.

Kızmaz, Z. (2006). Okullardaki şiddet davranışlarının kaynakları üzerine kuramsal bir yaklaşım. Cumhuriyet Üniversitesi Sosyal Bilimler Dergisi, 30(1), 47-70.

Metin-Aslan, Ö. ve Tuğrul, B. (2013). Anaokuluna devam eden çocukların oyun davranışları ve oyunlarında ortaya çıkan zorbalık davranışlarının incelenmesi. $A k$ deniz Eğitim Araștrmalan Dergisi, 13, 27-41.

Olweus, D. (1994). Bullying at school Long-term outcomes for the Victims and an Effective School-Based Intervention Program. (ed. by Huesmann, L.,R.). Agressive Behavior: Current Perspectives. Plenum Press, New York.

Perren, S. ve Alsaker, F. D. (2006). Social behavior and peer relationships of victims, bully-victims and bullies in kindergarten. Journal of Child Psychology and Pschiatry, 47(1), 45-57.

Pişkin, M. (2002). Okul zorbalığ: Tanımı, türleri, ilişkili olduğu faktörler ve alınabilecek önlemler. Kuram ve Uygulamada Eğitim Bilimleri, 2(2), 531-562.

Sabuncuoğlu, O., Ekinci, Ö., Bahadır, T., Akyuva, Y., Altınöz, E. ve Berkem, M. (2006). Ergen öğrenciler arasında akran örselemesi ve depresyon belirtileriyle ilişkisi. Klinik Psikiyatri, 9, 27-35.

Sall, G. (2014). Okulöncesi dönem çocuklarında akran ilişkilerinin ve akran şiddetine maruz kalmanın çeşitli değişkenler açısından incelenmesi. Çukurova Üniversitesi Eğitim Fakültesi Dergisi, 43(2), 195-216. 
Satan, A. (2006). İlköğretim ikinci kademe öğrencilerinin zorba davranıs eğilimlerinin okul türü ve bazı sosyo demografik değişkenler ile ilişkisi. Yayınlanmamış Doktora Tezi, Marmara Üniversitesi, Eğitim Bilimleri Enstitüsü, İstanbul.

Sezer, F, İşgör, IYY. (2010). İlköğretim ve ortaöğretim kurumlarındaki öğrencilerin problem alanlarınn tespiti: Erzurum ili örneği. Eğitim ve Sosyal Bilimler Dergisi, 39(186), 235-248.

Totan, T. (2008). Ergenlerde Zorbalığın Anne-Baba ve Akran Ilişkileri Açısından İncelenmesi. Yüksek Lisans Tezi, Abant İzzet Baysal Üniversitesi Sosyal Bilimler Enstitüsü, Bolu.

Türnüklü, A. ve Şahin, İ. (2002). Illköğretim okullarında öğrenci çatışmaları ve öğretmenlerin bu çatı̧malarla başa çıkma stratejileri. Kuram ve Uygulamada Ĕ̆itim Yönetimi, 8(30), 283-302.

Uçanok, Z., ve Uludağlı, N. (2005). Akran zorbalı̆̆ gruplarında yalnızlık ve akademik başarı ile sosyometrik statüye göre zorba/kurban davranış türleri. TürkPsikoloji Dergisi, 20(56), 77-92.

\section{Kaynakça Bilgisi / Citation Information}

Hamurcu, S. (2020). İlkokul öğrencilerinde akran zorbalığı: Ankara Pursaklar örneği. OPUS-Uluslararası Toplum Araştırmaları Dergisi, 16(32), 5540-5564. DOI: 10.26466/opus.758653 